\title{
Zaangażowanie w prace w perspektywie psychologii pozytywnej
}

\section{Streszczenie}

Zaangażowanie w pracę (job involvement), rozumiane jako jedna $\mathrm{z}$ form zaangażowania - obok zaangażowania organizacyjnego, w profesję i nadzór - najbardziej związane jest $\mathrm{z}$ indywidualnym zachowaniem. Jest ono rezultatem uwarunkowań o charakterze indywidualnym (postawy, motywacja) i społeczno-systemowym (styl zarządzania, kultura organizacji, wartości firmy). Budowanie tego typu zaangażowania w odwołaniu do koncepcji psychologii pozytywnej nie tylko stanowi wartość mierzalną dla przedsiębiorstwa, lecz także generuje wartość utajoną, którą można odnieść do podnoszenia poziomu dobrostanu pracowników. W ramach nurtu psychologii pozytywnej na przełomie wieków opisano specyfikę stanów optymalnego doświadczenia (flow), w których ludzie działają na granicy swoich możliwości, sięgając do swych unikatowych zasobów, i uzyskują znaczącą gratyfikację będącą wynikiem samego faktu działania w taki sposób. W artykule rozwinięto następujące tezy: zaangażowanie w wykonywaną czynność stanowi korelat nie tylko jakości wykonywanej pracy, ale również dobrostanu osobistego (szczęścia); zaangażowanie w wykonywaną czynność można ująć w koncepcji stanu optymalnego doświadczenia (absorpcji); z punktu widzenia organizacji najistotniejsze jest podejmowanie działań sprzyjających osiąganiu stanu absorpcji przez pracujących, jak też identyfikowanie oraz spożytkowywanie ich cech sygnaturowych.

Słowa kluczowe: przywiązanie, zaangażowanie, przepływ, praca, psychologia pozytywna, dobrostan.

Klasyfikacja JEL: D23, I12.

Mariusz Makowski, Uniwersytet Ekonomiczny w Krakowie, Wydział Ekonomii i Stosunków Międzynarodowych, Katedra Psychologii i Dydaktyki, ul. Rakowicka 27, 31-510 Kraków, e-mail: makowski@uek.krakow.pl 


\section{Wprowadzenie}

Problematyka niniejszego artykułu skupiona jest wokół zjawisk i procesów psychologicznych powiązanych z zaangażowaniem w pracę. Zwrócono w nim uwagę na wielość ujęć zaangażowania, jak również ich odrębność. Podkreślono istotność miar behawioralnych w szacowaniu poziomu zaangażowania pracownika. Podjęto też próbę umiejscowienia zaangażowania w pracę i zadowolenia z pracy (job involvement, job satisfaction) w kontekście założeń psychologii pozytywnej. Pozwoliło to na zaproponowanie trzech tez: 1) zaangażowanie w wykonywaną czynność stanowi korelat nie tylko jakości wykonywanej pracy, ale również dobrostanu osobistego (szczęścia), 2) zaangażowanie w wykonywaną czynność można ująć w koncepcji stanu optymalnego doświadczenia (absorpcji), 3) z punktu widzenia celów organizacji ważne jest podejmowanie działań sprzyjających osiąganiu stanu absorpcji u pracowników, jak też identyfikowaniu oraz spożytkowywaniu ich cech sygnaturowych. Przedstawiona propozycja - pochodząca z obszaru odkryć psychologii pozytywnej - jest kolejną, oryginalną metodą wzbogacania wartości pracy, na tle klasycznych podejść, takich jak spełnianie warunków krytycznych pracy J.R. Hackmana i G.R. Oldhama [1979] czy kluczowych wymiarów zadowolenia z pracy E. Scheina [1988].

\section{Zaangażowanie - dylematy definicji i pomiaru}

Zaangażowanie jest pojęciem ugruntowanym w naukach o zarządzaniu, niemniej jest ono różnie rozumiane. Skutkuje to trudnością w porównywaniu wyników badań poziomu zaangażowania, gdy jest się świadomym, że różni badacze odmiennie go definiują. Próbę uporządkowania typów zaangażowania podjęli Ch. Boshoff i G. Mels [2000]. Wyróżnili zaangażowanie w: organizację, pracę, profesję i sprawowany nadzór. Zaangażowanie w organizację (commitment to the organisation) oznacza wytworzenie więzów o charakterze emocjonalno-wzajemnościowo-kalkulatywnym między jednostką a organizacją. Zaangażowanie w pracę (czynność; job involvement) wiąże się z poziomem motywacji, zadowolenia oraz dopasowania do wykonywanych zadań. C. Boshoff i G. Mels [1995] używają w tym przypadku zamiennie określenia „zadowolenie z pracy” (job satisfaction). Zaangażowanie w profesję (zawód; professional commitment) dotyczy wykonywanej profesji; istotne są takie czynniki, jak wybór systemu wartości, poczucie kompetencji oraz identyfikacja zawodowa. Zaangażowanie w sprawowany nadzór (supervisor commitment) dotyczy poziomu wysiłków wkładanych w działania zarządcze, menedżerskie, mentorskie i kontrolne, jak 
również podzielania przez menedżerów wartości uznawanych przez przełożonych wyższego szczebla.

Przedstawiona typologia doskonale oddaje złożoność ludzkich postaw, motywacji, przekonań i działań, które próbuje się ująć w jednolitej i syntetycznej koncepcji zaangażowania w pracy. Warto zwracać uwagę na kwestię obszaru / obiektu zaangażowania pracownika, gdyż jednolita terminologia skrywa częstokroć różne procesy i zjawiska. Przykładowo zaangażowanie organizacyjne (organizational commitment) może dotyczyć głównie poziomu przywiązania/zależności od firmy, co samo w sobie niekoniecznie przekłada się na zadowalający pracodawcę poziom wykonywanej pracy i realizację celów organizacji (por. [Meyer i Allen 1991]) ${ }^{1}$. Podobnie zaangażowanie w profesję nie oznacza automatycznie, że pracownik będzie nagradzany przez pracodawcę; w wielu organizacjach pośrednio lub bezpośrednio promowane są działania pracowników korzystne dla przełożonych, niekoniecznie zaś dla ludzi, do służenia którym organizacja została powołana. Dobrym przykładem jest funkcjonowanie policji jako organizacji, która legitymizuje swe działania przedkładaniem statystyk wykrywalności przestępstw oraz interwencji. Bywa, że zaangażowany w swą pracę (profesję) policjant chce rozwikłać skomplikowaną sprawę, ale jest od tego odwodzony przez przełożonych, gdyż ci wolą promować działania, które w sposób bezpośredni, pewny oraz mało absorbujący środki i czas prowadzą do poprawy statystyk skuteczności działań policji.

W literaturze zaangażowanie pracownika ujmowane jest też jako koncepcja łącząca postawy, działania oraz transakcje (por. [Juchnowicz 2010, s. 34]). Zdaniem autora podział ten, choć analitycznie przydatny, nie jest zbyt fortunny z psychologicznego punktu widzenia ${ }^{2}$. Jedynie bowiem obserwacja/pomiar behawioralny mówi coś wprost o poziomie zaangażowania pracownika, podczas gdy wyznawane lub deklarowane postawy mogą w większym lub mniejszym stopniu z nim korelować i nie zawsze korelacja ta ma znak dodatni. Podobnie kryterium transakcyjne odnosi się do wyniku pewnej kalkulacji, działań opartych na wzajemności względem przedsiębiorstwa. Kiedy to poczucie wdzięczności jest niewielkie, trudno spodziewać się zaangażowania od pracownika, prawdopodobny jest raczej adekwatny poziom podejmowanych przez niego wysiłków. Koncepcja zaangażowania jako postawy jest popularna, zdaniem autora w dużym stopniu z powodu wygody operacyjnego jej mierzenia metodą kwestionariuszową.

${ }^{1}$ W szczególności dotyczy to zaangażowania określanego jako zaangażowanie trwania (continuance commitment).

2 Zakresy znaczeniowe tych pojęć zachodzą bowiem na siebie. Postawa zawiera element behawioralny. Wybór oparty na kalkulacji zawsze wynika z jakichś przekonań lub postaw (czasem ukrytych) i prowadzi do jakiegoś działania. Z kolei akty behawioralne poprzedzone są określonymi procesami myślowymi, do których należą również postawy, opinie, przekonania. 
Tymczasem do tego typu ludzkich deklaracji należy mieć zastrzeżenia. Wystarczy przywołać chociażby koncepcję zaproponowaną już niemal pół wieku temu przez Ch. Argyrisa i D. Schona [1974] dotyczącą teorii uznawanej i teorii stosowanej. Autorzy ci, studiując sposoby funkcjonowania organizacji, zauważyli, że procesy w nich zachodzące można opisać w dwóch różnych nurtach: tego, co się uważa, że jest (poziom deklaracji), oraz tego, co się w rzeczywistości robi (poziom rzeczywistej motywacji). Zdaniem badaczy większość ludzi nie jest świadoma jakiego rodzaju map mentalnych używa w swoim działaniu (postaw, motywów, przekonań), a mapy te są czymś odmiennym od teorii, które ludzie wygłaszają na temat tego, co robią. Biorąc to pod uwagę, dobrze zachować ostrożność wobec deklaracji w kwestionariuszach pomiaru zaangażowania rozumianego jako postawa, gdyż dane te wynikać mogą z tzw. teorii uznawanej - niekoniecznie prawdziwych przekonań podmiotu na swój temat. W późnych latach 70 . XX w. introspekcjonizmem ${ }^{3}$ w psychologii zachwiał metateoretyczny, przeglądowy artykuł R.E. Nisbetta i T.D. Wilsona [1977], w którym wypunktowano niedostatki ludzkich werbalnych wypowiedzi na temat własnych doświadczeń wewnętrznych, procesów motywacyjnych i emocjonalnych. Wymienione tu prace legły m.in. u podstaw nowych prądów metodologicznych, w szczególności w psychologii społecznej, w której wzrosła preferencja badań eksperymentalnych, obserwacji uczestniczącej, ale też badań jakościowych. Te ostatnie mają spory potencjał, jeśli chodzi o badania nad zaangażowaniem, w szczególności według metodologii action research. $\mathrm{Z}$ jej założeń wynika, że najcenniejsza wiedza pochodzi od ludzi autentycznie zaangażowanych w pracę, którzy mogą oraz powinni badać i opisywać proces, w którym uczestniczą. Innymi słowy, założenie główne jest takie, że znacznie cenniejszą wiedzę o zjawisku uzyskujemy, badając osoby typowe, które charakteryzują właściwości esencjalne zjawiska, niż działając w nurcie ilościowym, badać próbki z populacji - porównywać osoby reprezentujące różny stopień nasycenia cechą (w tym przypadku - poziom zaangażowania).

Warto zauważyć, że niektórzy autorzy zajmujący się psychologią zarządzania w ogóle nie używają pojęcia zaangażowania pracownika, lecz skupiają się na procesach motywacyjnych (por. [Makin, Cooper i Cox 2000]). Autor również stoi na stanowisku, że najbardziej warto przyglądać się zaangażowaniu w wykonywaną pracę jako skutkowi procesów motywacyjnych. Jest ono bowiem ostatecznym, obiektywnym, behawioralnym kryterium zarówno jakości wykonywanej pracy (co przekładać się może na realizację celów organizacji), jak i satysfakcji pracownika (realizacja celów osobistych). Warto tu zauważyć kolejną zależność - zadowolony pracownik, dostrzegający sens, ważność, wartość realizowanych przez siebie zadań, najprawdopodobniej będzie odczuwał wdzięczność wobec

${ }^{3}$ Nurt zakładający, że ludzie potrafią rzetelnie i wiarygodnie zdawać relację ze swoich psychicznych procesów wewnętrznych. 
organizacji, co wzmacnia zaangażowanie (przywiązanie) organizacyjne. Podobnie można założyć, opierając się na zależności wykazanej przez Ch. Boschoffa i G. Melsa [1995], że satysfakcja z pracy wpływa pozytywnie na przywiązanie do organizacji - u menedżera pochłoniętego czynnościami zarządczymi i przywódczymi będzie wzrastał poziom zaangażowania w nadzór. Wreszcie zatopienie w bieżących czynnościach łączy się z głębszym poznawaniem i przywiązaniem do wykonywanego zawodu przez proces identyfikacji oraz samodoskonalenia.

Ch. Boshoff i G. Mels [1995, s. 26] przedstawiają trzy główne elementy środowiska pracy, w którym pracownicy będą wykonywać swą pracę w sposób właściwy; są to: poziom identyfikacji pracownika z wartościami i celami organizacji, jasny sposób przedstawiania pracownikowi zadań do wykonania oraz poziom zadowolenia (satysfakcji) pracownika z wykonywanej pracy. W swych badaniach dowiedli bezpośredniego pozytywnego wpływu satysfakcji z pracy na zwiększanie przywiązania do organizacji. Jako znaczący czynnik pośredniczący wskazano partycypacyjny styl zarządzania. Jednocześnie odkryto szkodliwy wpływ niejasności przydzielanych zadań lub sprzecznych oczekiwań wobec pracownika na przeżywaną wewnętrznie satysfakcję z wykonywanej pracy. Wśród innych badaczy wiążących zaangażowanie z czynnikami emocjonalno-motywacyjno-behawioralnymi jednostki można wskazać W.B. Schaufeliego oraz A. Shiroma. W.B. Schaufeli i współpracownicy [2002] definiują zaangażowanie jako wypadkową trzech oddziałujących na siebie elementów: wigoru (vigor), oddania się pracy (dedication) oraz zaabsorbowania wykonywanymi zadaniami (absorbtion). Wigor oznacza doświadczanie wysokiego poziomu energii oraz odporności psychicznej podczas pracy. Z jego wysokiego poziomu wynika wysoki próg frustracji pracownika oraz zdolność pokonywania trudności i podejmowania wyzwań. Oddanie się pracy oznacza przydawanie znaczenia wykonywanej pracy, pojawiające się uczucia sensu, dumy, ważności podejmowanych czynności i ich skutków. Zaabsorbowanie zaś wiąże się z odczuwaniem stanu pełnej koncentracji, skupieniem na wykonywanym zadaniu, czego efektem jest doświadczanie kompresji czasu (czas, subiektywnie, zdaje się płynąć bardzo szybko). W podobny sposób centralną rolę wigoru postrzega A. Shirom [2003]. Według niego składają się nań: poczucie siły fizycznej (physical strength), stan umysłowo-poznawczego zaktywizowania (cognitive liveliness) oraz uczucie wypełnienia energią psychiczną (emotional energy). W przedstawionym kontekście satysfakcja z pracy rysuje się jako podstawowy składnik zaangażowania pracownika. Jest ona niejako pierwszym poziomem zaangażowania, na którym można nabudowywać kolejne, takie jak przywiązanie do organizacji, zaangażowanie w profesję lub - w przypadku menedżera - zaangażowanie w nadzór. W dalszej części artykułu autor przedstawia sposoby wzbogacania satysfakcji z pracy przez tworzenie warunków 
do osiągania stanu przepływu (flow), jak również detekcji i spożytkowania najlepszych kompetencji pracowników - ich sił sygnaturowych.

\section{Zaangażowanie a psychologia pozytywna}

Celem artykułu jest powiązanie problematyki zaangażowania $\mathrm{w}$ pracę $\mathrm{z}$ wynikami badań w obszarze psychologii pozytywnej. Autor przedstawia i uzasadnia trzy następujące tezy:

- zaangażowanie w wykonywaną czynność stanowi korelat nie tylko jakości wykonywanej pracy, ale również dobrostanu osobistego (szczęścia),

- zaangażowanie w wykonywaną czynność można ująć w koncepcji stanu optymalnego doświadczenia (absorpcji),

- z punktu widzenia organizacji ważne jest podejmowanie działań sprzyjających osiąganiu stanu absorpcji przez pracujących, jak i identyfikowaniu oraz spożytkowywaniu ich cech sygnaturowych.

Psychologia pozytywna stanowi stosunkowo nowy, bo ledwie 20-letni, nurt w badaniach i praktyce psychologicznej. Proponuje ona nie tyle odmienną metodologię badań, co sposób podejścia, postrzegania obiektu badań. Koncentruje się na czynnikach, tak indywidualnych, jak społecznych i środowiskowych, które podtrzymują człowieka w dobrej formie psychofizycznej, pozwalają mu zachować zdrowie i odporność psychiczną, zasilają motywację, pozwalają zdobywać mądrość oraz podnosić poziom dobrostanu i szczęścia. Inaczej niż w dotychczas dominującym nurcie, w którym skupiono się na wychwytywaniu zaburzeń lub neutralnym opisywaniu zjawisk i procesów psychicznych, psychologia pozytywna koncentruje się na identyfikowaniu i wzmacnianiu czynników podtrzymujących: zdrowie, mocne strony człowieka, jego zasoby, potencjał służący rozwojowi i doświadczanie szczęścia. Za twórców psychologii pozytywnej uważani są M. Seligman i M. Csiksentmihalyi [2000a]. W Polsce aktywnie promuje ją swymi badaniami nad szczęściem autor „,cebulowej teorii szczęścia”, J. Czapiński [2005].

Postawione powyżej tezy można syntetycznie ująć w następujący wywód: droga do zwiększania zaangażowania w pracę zależy w istotnym stopniu od stworzonych danej osobie warunków do przeżywania w pracy stanu flow ${ }^{4}$. $\mathrm{Z}$ osiągania stanów tego rodzaju płyną korzyści nie tylko dla organizacji, ale również dla pracownika. Z kolei wyższy poziom dobrostanu zatrudnionej osoby w sprzężeniu zwrotnym dodatnim wpływał będzie na długoterminowe zaangażowanie organizacyjne - przez zasadę wdzięczności, czyniąc zeń lojalnego pracownika. Zada-

${ }^{4}$ Autor zamiennie używa określeń „stan flow”, flow i „przepływ”. W literaturze pojęcie to tłumaczone jest również jako „stan absorpcji”, „stan na fali”, „zaabsorbowanie”. Uniwersalna pełna nazwa to „stan optymalnego doświadczenia”. 
niem pracodawcy jest $\mathrm{w}$ tym procesie stworzenie przestrzeni do doświadczania stanów flow. Droga do tego prowadzi przez działania diagnostyczno-rekrutacyjne, dobór adekwatnego stylu zarządzania, kreowanie określonej kultury organizacyjnej oraz nieustanny proces kształcenia kadr w szerokim tego słowa znaczeniu (działania integracyjne, coachingowe, mentoring).

Zaangażowanie nierozerwalnie związane jest z motywacją człowieka, zależy od niej bezpośrednio, ale w pojęciu tym zawarty jest również składnik behawioralny. W psychologii z poziomu motywacji u danego człowieka wnioskuje się o możliwych działaniach. Warto jednak pamiętać, że to, czy relatywnie wysoki poziom motywacji przełoży się na działanie celowe, zależy od kilku czynników pośredniczących. Można tu wskazać np. proces habituacji związany z nagrodami, obecny konflikt motywów czy też wysoki poziom lęku. Innymi słowy, mimo środowiska o dużym potencjale motywacyjnym pracownik nie wykazuje zaangażowania $\mathrm{w}$ działaniu i nie pracuje z pasją. W psychologii pozytywnej dużą wagę przywiązuje się do motywacji wewnętrznej (intrinsinc, motywacja autoteliczna ${ }^{5}$ ). W odróżnieniu od motywacji zewnętrznej jest ona względnie odporna na zakłócenia takie jak habituacja czy konflikt wartości. Do jej zalet należy ekonomiczność w sensie samonapędzającej się natury, raz uruchomiona motywacja autoteliczna będzie wzbudzana minimalnym wysiłkiem, charakterystyczna jest też natychmiastowość i adekwatność gratyfikacji psychicznej, jakiej dostarcza. Właśnie wartość gratyfikacyjna zwróciła uwagę badaczy psychologii pozytywnej na ten rodzaj motywacji. Regularne działanie pod jej wpływem w istotny sposób wpływa bowiem na zwiększenie dobrostanu człowieka, a pośrednio na jego poziom szczęścia.

\section{Optymalne doświadczenie}

Stan optymalnego doświadczenia (flow, absorpcja, przepływ) według M. Csikszentmihalyi [1996] jest stanem psychologicznym, który cechują całkowite pochłonięcie wykonywaną czynnością, utrata poczucia czasu, poczucie siły, kontroli, koncentracji, siły i radości. Pojawia się on, kiedy bierzemy udział w ambitnych, ale mieszczących się w naszych kompetencjach, motywujących wewnętrznie działaniach. Stan ten jest w wysokim stopniu nagradzający i ludzie podejmują wysiłki, aby go ponownie doświadczać. Czynnik wyboru - filar motywacji wewnętrznej - sprawia, że ludzie doznają stanu flow podczas aktywności hobbistycznych czy sportowych w czasie wolnym, badania przeprowadzone przez M. Csiksentmihalyi

5 Określenie ,autoteliczny” - będący celem sam dla siebie, w kontekście motywacji oznacza aktywność, która jest uruchamiana ze względu na nagrody związane z nią samą, z samą czynnością, bez zewnętrznych motywów. 
[1996, s. 277] pokazują jednak coś innego. Paradoksalnie wykazał on, że ludzie częściej doświadczali stanu flow w pracy niż w czasie wolnym. Wiarygodności danym tym przydaje eksperymentalny charakter badań opartych na metodzie dzienników oceny aktywności pracowników, którzy przez cały czas pracy w losowo wybranych momentach na sygnał pagera oceniali poziom zaabsorbowania pracą. Wyniki pokazały, że kiedy pager odzywał się w momentach dużego obciążenia pracą (co stanowiło przeciętnie $75 \%$ czasu w pracy), doświadczenia flow pracowników wynosiły $54 \%$. W czasie wolnym udział ten wynosił tylko 18\%. M. Csiksentmihalyi [1996, s. 281] komentuje ten zaskakujący wynik (wszak czas wolny kojarzy się z wolnością wyboru aktywności, a praca z ograniczeniem tej wolności), odwołując się do motywacyjnego znaczenia celów podejmowanej aktywności. Jeżeli cele wyznaczane przez organizację są równocześnie celami jednostki (co zwykle oparte jest na zgodności wartości, które za nimi stoją) i są odpowiednio ambitne (warunek flow), pracownik z jednej strony doświadcza spójności wewnętrznej (,pracuję dla NAS”), z drugiej zyskując wsparcie przełożonych w utrzymaniu odpowiednio wysokiego poziomu zaangażowania w działanie, może zrealizować drugi kluczowy warunek stanu flow. Spostrzeżenie to spójne jest z danymi wynikającymi z badań dotyczących czynników budujących wartość pracy. Przykładowo J.R. Hackman i G.R. Oldham [1979] jako czynniki kluczowe (krytyczne) nadające uniwersalnie wartość pracy wskazują jej znaczenie (ważność) dla człowieka, poczucie odpowiedzialności za swoje czyny oraz możliwość regulowania sposobów wykonywania pracy na podstawie realistycznej i rzetelnej informacji zwrotnej z otoczenia. Można to przełożyć na: dopasowanie, dojrzałość oraz wolność i autonomię. Jeszcze precyzyjniejszą receptę na osiąganie stanu flow dał teoretyk problematyki kultury organizacyjnej, E. Schein [1988]. Przedstawił on koncepcję pozytywnych stanów psychicznych przeżywanych w pracy; są to: różnorodność wymagań i umiejętności (kompetencji), kompletność wyznaczanych zadań, znaczenie zadań (powiązanie ich z wartościami organizacyjnymi, społecznymi i osobistymi), autonomia pracownika dotycząca sposób wykonywania pracy oraz udzielanie informacji zwrotnej (oceny, informacja o wynikach pracy). Równocześnie E. Schein nie zapomina o obszarze odpowiedzialności po stronie jednostki, dotyczącej współtworzenia warunków sprzyjających stanom pozytywnego przeżywania pracy. Wskazuje na: poziom indywidualnych kompetencji, wiedzy i predyspozycji, obecność motywacji rozwoju i osiągnięć oraz nasycenie potrzeb podstawowych, zabezpieczenie finansowe (godziwa płaca), socjalne, bezpieczeństwo warunków pracy.

Trzecia, główna teza niniejszego artykułu dotyczy powiązania stanu flow z identyfikacją i rozwijaniem cech sygnaturowych pracowników. Jak wspomniano, platformę dla tego stanu tworzą: 1) atraktor samej czynności, która - w określony sposób wykonywana - jest psychologicznie bardzo nagradzająca, 2) odpowiednio 
wysoko postawione wymagania (trudność), będące wyzwaniem, 3) zasoby jednostki na tyle duże, że spełnienie ambitnych wymogów jest realne. Psychologia pozytywna za sprawą M. Seligmana [2002] zyskała koncepcję sił sygnaturowych oraz powiązanych z nimi cnót i cech charakteru, które pozostają w ścisłym związku z możliwością podnoszenia poziomu dobrostanu jednostki, a w konsekwencji szczęścia. Ch. Peterson i M. Seligman [2004] wyróżniają sześć cnót głównych, stanowiących kluczowe wartości: mądrość, odwagę, człowieczeństwo, sprawiedliwość, powściągliwość i transcendencję. Każda z tych cnót - wartości, łączy się z określonymi cechami charakteru, zwanymi siłami sygnaturowymi. Przykładowo powściągliwość związana jest z takimi siłami, jak: skromność i pokora, rozwaga, ostrożność, dyskrecja, przezorność oraz samokontrola, panowanie nad sobą. Z kolei człowieczeństwo powiązane jest z takimi siłami, jak: zdolność do kochania i przyjmowania miłości oraz uprzejmość i hojność 6 . Założenie jest następujące: wysoki, na granicy możliwości wykonania, poziom działania jest ludziom dostępny w tych aktywnościach, do których mają predyspozycje, zgromadzone bogate zasoby wiedzy, umiejętności, doświadczenia. Skuteczniejsze jest opieranie się na mocnych stronach niż inwestowanie w rozwój cech, zdolności drugo- i trzeciorzędnych w profilu osobowościowo-charakterologicznym osoby. Oczywiście jest tu mowa o potencjale do przeżywania stanu przepływu. Stąd wyzwaniem zarządczym staje się identyfikacja zarówno cnót osobistych, jak i sił sygnaturowych pracownika. Proces ten rozpoczyna się już w momencie rekrutacji, a nawet wcześniej, gdy potencjalny pracownik, przygotowując swoje $\mathrm{CV}$, dokonuje samooceny. W dalszej kolejności pracownik weryfikuje swą ocenę podczas zdobywania doświadczenia zawodowego. Reprezentanci organizacji mają możliwość dokonywania korekt, polegających zarówno na urealnieniu umiejętności pracownika, jak też na odpowiedniej ich stymulacji. Dokonywać się to może przez dobór stylu kierowniczego, szkoleń, modelowania, ale też rotację na różnych stanowiskach. Kluczowe w tych działaniach jest realistyczne odnoszenie się do potencjału sygnaturowego danej osoby. Czynniki, takie jak ,awans z wysługi lat”, „zasługiwanie” czy „chwilowy wakat na stanowisku”, nie powinny być brane pod uwagę. Kiedy bowiem grają one pierwszoplanowa rolę, awansowanej osobie wyświadcza się niedźwiedzią przysługę, choć metafora ta odnosi się do całej organizacji: sam fakt awansu nie sprawi, że osoba ta rozwinie motywację wewnętrzną i zyska większą możliwość doświadczania przepływu. Powszechny (i szkodliwy) pogląd, że automatyczną odpowiedzią na awans jest zwiększone zaangażowanie pracownika,

${ }^{6} \mathrm{~W}$ artykule przedstawiono tylko dwie cnoty oraz odpowiadające im siły sygnaturowe. W rzeczywistości występują 24 siły sygnaturowe, których pełny opis można znaleźć w pracy [Peterson i Seligman 2004] lub w wersji popularnonaukowej w pracy [Blum 2009]. Online dostępny jest przegląd koncepcji i opis klasyfikacji VIA: http://www.viacharacter.org/www/Character-Strengths/ VIA-Classification (data dostępu: 16.05.2017). 
nie ma umocowania $w$ założeniach psychologii pozytywnej, w każdym razie jeśli zaangażowanie rozumieć jako regularne doświadczanie stanu flow w pracy. Rzeczywiście, pracownicy zwiększają wysiłek, pracują dłużej i ciężej, po części w poczuciu lojalności wobec pracodawcy, po części z lęku (nie zawsze uświadamianego) przed utratą stanowiska, stratą częstokroć postrzeganą jako porażka lub degradacja.

\section{Cnoty i siły sygnaturowe}

Do diagnozy sił sygnaturowych charakteru Ch. Peterson i M. Seligman [2004] opracowali tzw. inwentarz sił charakteru (values in action inventory of strengths - VIA-IS). Oparty na 240 pytaniach samoopisowych kwestionariusz dostarcza wiedzy o specyficznej u danej osoby hierarchii sił sygnaturowych (charakteru) ${ }^{7}$. Dodatkowo M. Seligman [2002] proponuje weryfikację uzyskanego profilu przez sprawdzenie, na ile charakteryzujące badanego siły charakteru odnoszą się do wybranych kryteriów. Są to kolejno: 1) wywoływanie radości, entuzjazmu, zapału lub nawet stanu uniesienia podczas działania opartego na danej sile, 2) tworzenie osobistych planów, które dotyczą tej siły, ożywienie dominujące nad zmęczeniem podczas używania danej siły, 3) poczucie regularnego spożytkowywania tej siły w życiu codziennym, 4) uczenie się wciąż nowych sposobów wykorzystania danej siły, 5) szybkie uczenie się, gdy siła ta używana jest po raz pierwszy, 6) podekscytowanie na samą myśl o korzystaniu z tej siły oraz 7) przekonanie, że dana siła jest jednym z podstawowych atrybutów psychicznych osoby. Z inwentarza VIA-IS można skorzystać nieodpłatnie online ${ }^{8}$. Wynik pokazuje hierarchię najaktywniejszych sił sygnaturowych w polu osobowościowym oraz związane z nimi cnoty (wartości) osobowe. Stanowi to określone wyzwanie dla układu pracownik-organizacja. Może być bowiem tak, że główne zasoby danej osoby koncentrują się wokół takich cnót jak odwaga i człowieczeństwo - odpowiadają im siły sygnaturowe, takie jak: waleczność, prawość, wytrwałość, szczerość, integralność, autentyczność oraz uprzejmość, hojność oraz zdolność do kochania, podczas gdy osoba ta pracuje w miejscu, gdzie wartości te nie są szczególnie cenione (choć deklaracje kadry zarządczej mogą świadczyć o czymś innym). Wskazuje to na istotność właściwego dopasowania osoby do miejsca pracy. Jak zauważa M. Seligman [2002], spożytkowanie „charakterologicznego przeznaczenia” w postaci indywidualnej mozaiki cech sygnaturowych dokonuje się w holistyczny sposób, nie tylko w sferze spełnienia zawodowego. W równym stopniu opieramy się na tych siłach w ważnych

${ }^{7}$ Podskale (24) kwestionariusza VIA-IS skorelowane są ze skalami kwestionariusza osobowości mierzącego główne cechy osobowości „wielkiej piątki”, co jest probierzem rzetelności testu.

${ }^{8}$ http://www.viacharacter.org/www/Character-Strengths-Survey (data dostępu: 16.05.2017). 
życiowych związkach z innymi (z rodzicami, partnerami, potomstwem), jak też w aktywnościach poza pracą. Można postawić hipotezę, że pomiędzy tymi scenami aktywności życiowej dokonuje się transfer doświadczeń. Głębokie poczucie sensu $\mathrm{z}$ własnej rodziny mogłoby przenosić się w sferę pracy i np. doświadczenia wychowawcze $\mathrm{z}$ własnymi dziećmi owocowałyby oryginalnymi rozwiązaniami zarządczymi w zespole pracowniczym, i na odwrót - dobre doświadczenia w pracy mogą skutkować np. zaangażowanym ojcostwem lub rozwijaniem zainteresowań, które przeradzają się w pasję (sport, sztuka, zaangażowanie społeczne). Do stawiania takich hipotez upoważniają bardzo interesujące badania przeprowadzone przez J.H. Fowlera i A. Christakisa [2008], które dowiodły występowania zjawiska rozprzestrzeniania się szczęścia (contagion of happiness) w sieciach ludzkich. Autorzy ci - na postawie 20-letnich badań podłużnych - doszli do wniosku, że ludzie zarażają się nawzajem poczuciem szczęścia. Dowiedli, że poczucie szczęścia ludzie przekazują sobie przez sam fakt interakcji i pozostawania w relacjach. Jest to wyraźne aż do kontaktów trzeciego stopnia, tzn. widoczny jest pozytywny wpływ szczęśliwej osoby na drugą osobę, ale również jej znajomego oraz znajomego tego znajomego. Co więcej, przez obserwację i analizę sieci społecznych, w jakich dany człowiek funkcjonuje (nasycenie szczęściem), można wiarygodnie przewidzieć poziom szczęścia tej osoby na kilka lat do przodu. Warto dbać o dostarczanie ludziom optymalnego doświadczenia, gdyż ono przekłada się na możność podnoszenia poziomu szczęścia.

\section{Podsumowanie}

$\mathrm{W}$ artykule zaproponowano spojrzenie na zaangażowanie z perspektywy psychologii pozytywnej. Oznacza to, że stan ten nierozerwalnie łączy się z kluczowymi - według tego podejścia psychologicznego - motywami ludzkiej aktywności, takimi jak dążenie do podnoszenia poziomu dobrostanu i szczęścia oraz realizacja własnych wrodzonych predyspozycji. Mechanistyczne metody stymulowania zaangażowania pracowników, oparte na motywacji zewnętrznej9, jakkolwiek chwilowo skuteczne, mają wiele ograniczeń, jeśli chodzi o użyteczność i skuteczność. Motywatory nierzadko stają w konflikcie z osobistymi przekonaniami i wartościami, a proces habituacji odbiera mi początkową siłę wpływu. Najcenniejszym, $\mathrm{w}$ istocie niewyczerpanym źródłem zaangażowania ludzi w pracy są: poczucie autonomii, możliwość dążenia do mistrzostwa oraz poczucie celu (por. [Pink 2011]). Uzyskiwanie stanu przepływu jest ucieleśnieniem realizacji tych dążeń. Można prowokacyjnie zapytać: skoro ludzie mogą doświadczać szczęścia w swej

${ }^{9}$ Motywację zewnętrzną, w odróżnieniu od motywacji wewnętrznej, cechuje oddzielenie czynności od nagrody. 
pracy, dlaczego im tego nie umożliwić? Być może jest to pytanie aksjologiczne. Dla zarządzających, akcjonariuszy zorientowanych stricte ekonomicznie, liczy się efektywność i konkurencyjność prowadzonego przedsiębiorstwa, które zależą od zaangażowania pracowników. Warto obalić stereotyp, że ciężka, zaangażowana praca łączy się z trudem, mozołem, a nierzadko także frustracją. Drugą, ukrytą częścią tego stereotypu jest przekonanie, że poczucie szczęścia, satysfakcji daje ludziom to, co robią w czasie wolnym, w sferze prywatnej, rodzinnej. Takie założenie jest wygodne dla pracodawców, gdyż zdaje się zwalniać ich z odpowiedzialności nadania sensu pracy i takiego jej wzbogacenia, aby umożliwiała stan przepływu, a pośrednio - podniesienie poziomu dobrostanu psychicznego. Psychologia pozytywna dowodzi, że człowiek w każdym punkcie swego życia stanowi całość, również w roli pracownika, i że możliwe jest godzenie i zaspokajanie różnych potrzeb w miejscu pracy. Jednymi z kluczowych potrzeb są poczucie sensu oraz potrzeba osiągnięć. Nawet jeżeli są one ukryte pod bieżącymi celami codzienności, takimi jak zdobywanie środków na utrzymanie, pozostają aktywne. Zaniedbywanie ich rzutuje bezpośrednio na poziom zaangażowania w pracę.

Możliwość regularnego doświadczania stanu flow skutkuje wyższym poziomem odczuwania szczęścia. Powstaje pętla oddziaływania. Szczęśliwszy pracownik spełnia z nawiązką wymogi kontraktu psychologicznego między nim a pracodawcą. Jest lojalny, sumienny, dobrze mówi o pracodawcy poza firmą, jest wdzięczny, co przykłada się na ofertę ponadnormatywnego nakładu pracy w okresach, kiedy jest to kluczowe dla pracodawcy (np. w sytuacjach kryzysowych). „Pozytywność” doświadczenia zaangażowania wykracza poza sferę kontraktu organizacyjnego, rzutuje na sferę prywatną, rodzinną, możliwość zaangażowania społecznego, obywatelskiego. Ludzie realizujący się w pracy, mają większe poczucie własnej wartości, skuteczności i sprawczości w innych sferach społecznego funkcjonowania. Poczucie szczęścia zbudowane w pracy oddziałuje na całe życie człowieka, na jego interakcje z innymi.

\section{Literatura}

Argyris Ch., Schon D. [1974], Theory in Practice. Increasing Professional Effectiveness, Jossey-Bass, San Francisco, CA.

Blum R. [2009], Psychologia pozytywna w praktyce. 6 cnót głównych i 24 siły dające szczęście, Bauer - Weltbild Media, Warszawa.

Boshoff Ch., Mels G. [1995], Role Stress and Job Satisfaction: Their Supervisory Antecedents and Their Influence on Organizational Commitment, ,Journal of Industry Psychology", vol. 21, nr 1, https://doi.org/10.4102/sajip.v21i1.585.

Boshoff Ch., Mels G. [2000], The Impact of Multiple Commitments on Intentions to Resign: An Empirical Assessment „British Journal of Management”, vol. 11, nr 3, https://doi.org/10.1111/1467-8551.00165. 
Csikszentmihalyi M. [1996], Przepływ. Jak poprawić jakość życia, Studio Emka, Warszawa.

Czapiński J. [2005], Psychologiczne teorie szczęścia [w:] Psychologia pozytywna. Nauka o szczęściu, zdrowiu, sile i cnotach człowieka, red. J. Czapiński, Wydawnictwo Naukowe PWN, Warszawa.

Fowler J.H., Christakis N.A. [2008], Dynamic Spread of Happiness in a Large Social Network: Longitudinal Analysis over 20 Years in the Framingham Heart Study, „British Medical Journal", vol. 337, https://doi.org/10.1136/bmj.a2338.

Hackman J.R., Oldham G.R. [1979], Work Redesign, Addison-Wesley, Reading, Mass.

Juchnowicz M. [2010], Zarzqdzanie przez zaangażowanie. Koncepcje, kontrowersje, aplikacje, PWE, Warszawa.

Makin P., Cooper C., Cox Ch. [2000], Organizacje a kontrakt psychologiczny. Zarzqdzanie ludźmi w pracy, Wydawnictwo Naukowe PWN, Warszawa.

Meyer J.P., Allen N.J. [1991], A Three-component Conceptualization of Organizational Commitment, „Human Resource Management Review”, vol. 1, nr 1, https://doi.org/ 10.1016/1053-4822(91)90011-z.

Nisbett R.E., Wilson T.D. [1977], Telling More than We Can Know: Verbal Reports on Mental Processes, „Psychological Review”, vol. 84, nr 3, https://doi.org/10.1037// 0033-295x.84.3.231.

Peterson Ch., Seligman M.E.P. [2004], Character Strengths and Virtues: A Handbook and Classification, Oxford University Press and Washington, American Psychological Association, New York, http://www.viacharacter.org/www/Character-Strengths-Survey; http://www.viacharacter.org/www/Character-Strengths/VIA-Classification (data dostępu: 16.05.2017).

Pink D.H. [2011], Drive. Kompletnie nowe spojrzenie na motywacje, Studio Emka, Warszawa.

Schaufeli W.B., Salanova M., Gonzalez-Roma V., Bakker A.B. [2002], The Measurement of Engagement and Burnout: A Two Sample Confirmatory Factor Analytic Approach, „Journal of Happiness Studies”, vol. 3.

Schein E. [1988], Organizational Psychology, Prentice Hall, Englewood Cliffs, NJ.

Seligman M. [2002], Authentic Happiness: Using the New Positive Psychology to Realise Your Potential for Lasting Fulfilment, Free Press, New York.

Seligman M., Csiksentmihalyi M. [2000], Positive Psychology: An Introduction, „American Psychologist", vol. 55, nr 1, https://doi.org/10.1037//0003-066x.55.1.5.

Shirom A. [2003], Feeling Vigorous at Work? The Construct of Vigor and the Study of Positive Affect in Organizations, ,Research in Organizational Stress and Well-being”, vol. 3, https://doi.org/10.1016/s1479-3555(03)03004-X.

\section{Job Involvement and Positive Psychology}

(Abstract)

Job involvement, understood as one form of commitment - alongside organisational commitment, professional commitment and supervision - is the one most linked with a person's behaviour. It results from individual characteristics (attitudes, motivation) determinants as well as social-system factors (management style, organisational culture, well-being). Developing this type of commitment in reference to the concept of positive 
psychology makes not only tangible assets easily calculated in business, but generates intangible assets that may help raise employee well-being and happiness. Positive psychology, at the beginning of the century described the specifics of the states of optimal experience ("flow") in which people act at the limits of their capabilities, reaching out with their most specialised resources and, in turn, gaining significant gratification as a result of the mere act of "high turnover". The article develops the following theses: job commiment correlates positively not only with the quality of work but also with personal well-being (happiness), job commitment may be conceptualised by state of optimal experience (absorption), in the organisational perspective it should be essential to promote the achievement of "flow" experiences by employees as well as to identify and use their signature strengths.

Keywords: commitment, involvement, flow, job, positive psychology, well-being. 